\title{
Cultural and Morphological Characterization of Antagonistic Trichoderma Isolates
}

\author{
Priya Singh $^{1^{*}}$ and Manju Sharma ${ }^{2}$ \\ ${ }^{1}$ Department of Plant Pathology, Dr. Rajendra Prasad Central Agricultural University, \\ Pusa, Samastipur - 848125, India \\ ${ }^{2}$ College of Agriculture, Department of Plant Pathology, Govind Ballabh Pant University of \\ Agriculture and Technology, Pantnagar - 263145, India \\ *Corresponding author
}

\section{A B S T R A C T}

\begin{tabular}{|l|}
\hline Ke y w o r d s \\
Trichoderma, \\
Rhizosphere, \\
Characterization, \\
Cultural, \\
Morphological \\
\hline Article Info \\
\hline $\begin{array}{l}\text { Accepted: } \\
\text { 05 February 2020 } \\
\text { Available Online: } \\
\text { 10 March 2020 }\end{array}$ \\
\hline
\end{tabular}

In this study, the fifteen isolates of Trichoderma were obtained from rhizospheric soil samples of rice, soybean and mungbean from various locations of Pantnagar and Dehradun. These isolates were characterized based on their cultural and morphological characteristics. The cultural characteristics like colony colour, presence or absence of concentric rings, surface topography, pigmentation on the lower side of the plate, time of first appearance of green conidia and their growth at various temperatures were determined on the basal medium Potato Dextrose Agar. The morphological characters like conidiophores, their branching pattern, phialides number, their arrangement, conidial shape and formation of chlamydospores were observed under the microscope.

\section{Introduction}

The genus Trichoderma is of immense economic importance due to their ability to control a wide array of plant pathogens. They employ several mechanisms like mycoparasitism, antibiosis, competition for space and nutrients, stimulating plant health and inducing plant defenses for managing several harmful plant pathogens. The isolates of Trichoderma were differentiated on the basis of cultural characteristics like colony colour, presence or absence of concentric rings, surface topography and pigmentation on lower side of the plate as well as morphological characteristics including conidiophores, phialides and phialospores (Seaby, 1996). Several workers have classified the isolates of Trichoderma on basis of their cultural and morphological characteristics (Rifai and Webster, 1996; Kiffer and Morelet, 2000; Samuels et al., 
2002). These cultural and morphological characteristics of Trichoderma play a key role in identification of species of Trichoderma. This study was carried out to study the variability among the Trichoderma isolates on basis of their cultural and morphological characteristics.

\section{Materials and Methods}

\section{Sample collection and isolation}

The fifteen isolates of Trichoderma were obtained according to the method given by Elad et al., (1981) using serial dilution (Krassilnikov, 1950) on Trichoderma selective medium (TSM). The Trichoderma isolates were obtained from the rhizospheric soils of soybean, rice and mungbean from various locations of Pantnagar and Dehradun (Table 1).

\section{Cultural and morphological characterization of trichoderma isolates}

The cultural and morphological characteristics of fifteen Trichoderma isolates were determined on Potato Dextrose Agar (PDA). A $5 \mathrm{~mm}$ disc of each Trichoderma isolates was cut from the edge of actively growing fresh colony using sterile cork borer and was transferred to Petri plates containing PDA with mycelium facing downwards. Three replications were maintained for each treatment. The plates were incubated at $28 \pm 1^{\circ} \mathrm{C}$ and the colonies were examined at every $24 \mathrm{hrs}$ interval.

The observations on cultural characters like colony colour, presence or absence of concentric rings, surface topography, pigmentation on lower side of the plate, time of first appearance of green conidia were recorded. For morphological studies microscopic slides were prepared from 3-7 days old culture by taking a thin section of fresh hyphal tips with help of sterilized inoculating needle in a drop of lactophenol cotton blue solution on to the slide. The hyphae and conidiophores were separated before placing coverslip with the help of needle.

Excess mounting fluid was drained with a clean blotting paper. The cultures were incubated upto 2 weeks at $20^{\circ} \mathrm{C}$ to observe chlamydospores. The slides were observed under the microscope for the characters like conidiophores, their branching pattern, phialide numbers, their arrangement, conidial shape and formation of chlamydospores.

\section{Results and Discussion}

\section{Cultural characteristics and growth rate of trichoderma isolates}

The cultural characteristics of Trichoderma isolates were studied on basal medium PDA The maximum mycelial growth was recorded at $25^{\circ} \mathrm{C}$ showing colony diameter of $87 \mathrm{~mm}$ to $90 \mathrm{~mm}$ after 72 hours followed $20^{\circ} \mathrm{C}$ and $30^{\circ} \mathrm{C}$ and abnormal colonies with irregular margins were observed at $35^{\circ} \mathrm{C}$. Among the fifteen isolates, 4 were dark green, 2 were light green, 7 were light to dark green and 2 were whitish to light green in colour. Eleven isolates (PT-1, 2, 4, 6, 7, 8, 9, 10, DDNT-1, 2, and 3 ) showed concentric ring formation.

Eleven isolates exhibited rough, spongy and raised colony, two showed smooth and flat colony, one isolate was having smooth and flat colony with dense sporulation at border and one showed spongy and fluffy growth. One isolate produced light brown pigmentation, 5 showed whitish creamy, 3 yellowish, 5 yellowish green and 1 pinkish pigmentation on the reverse side of the plate. Seven isolates produced conidia at $48 \mathrm{hrs}$, three at 48-72 hrs and one at $72 \mathrm{hrs}$ (Plate 1 and Table 2). 
Morphological characterization of trichoderma isolates

All the isolates were branched at right angle, the branching pattern was difficult to define. Primarily two types of phialides were observed i.e. lageniform and ampulliform. Conidia were globose, subglobose and globose to subglobose, globose to ellipsoidal and green in colour. Chlamydospores were either terminal or intercalary or both in some isolates as presented in Table 3 and Plate 2. On the basis of morphological characteristics as presented in Table 3 the Trichoderma isolates were grouped into four categories (Table 4).

Colony of Trichoderma usually grow rapidly, initially smooth surface, almost translucent or watery and later became floccose or compactly tufted, in various shades of pure white or green. Trichoderma colonies secreted pigments into the medium or reverse side of plates (Mukherjee, 1991). Cultural characters such as growth rate, colour and appearance of the colonies were considered as taxonomically important characters (Samuels et al., 2002). Sharma (2009) characterized the Trichoderma isolates of Uttarakhand based on culture colour, pigmentation, conidiation and growth rate. Erayya (2014) also observed the characters like colour of the colony, formation of concentric rings, surface topography and pigmentation on the reverse side of the plate to characterize the Trichoderma isolates from Uttarakhand.

Table.1 Soil samples collected from different locations

\begin{tabular}{|l|l|l|l|}
\hline S. No. & Location & Site & Crop \\
\hline 1. & Pantnagar & Agronomy block, CRC & Soybean \\
\hline 2. & Pantnagar & Agronomy block, CRC & Rice \\
\hline 3. & Pantnagar & Plant Pathology block, CRC & Soybean \\
\hline 4. & Pantnagar & Plant Pathology block, CRC & Rice \\
\hline 5. & Pantnagar & Plant Pathology block, CRC & Mungbean \\
\hline 6. & Pantnagar & Breeding block, CRC & Soybean \\
\hline 7. & Pantnagar & Entomology block, CRC & Soybean \\
\hline 8. & Pantnagar & Agrometeorology block, CRC & Soybean \\
\hline 9. & Pantnagar & Breeding block, CRC & Rice \\
\hline 10. & Pantnagar & Entomology block, CRC & Rice \\
\hline 11. & Dehradun & Premnagar & Soybean \\
\hline 12. & Dehradun & Bhaniawala & Soybean \\
\hline 13. & Dehradun & Raipur & Soybean \\
\hline 14. & Dehradun & Mehuwala & Soybean \\
\hline 15. & Dehradun & Doiwala & Soybean \\
\hline
\end{tabular}

*CRC - N. E. Borlaug Crop Research Center, Pantnagar 
Table.2 Cultural characteristics of Trichoderma isolates

\begin{tabular}{|c|c|c|c|c|c|c|}
\hline $\begin{array}{l}\text { S.No } \\
\cdot\end{array}$ & $\begin{array}{l}\text { Isolate } \\
\text { code }\end{array}$ & $\begin{array}{l}\text { Colony } \\
\text { colour }\end{array}$ & $\begin{array}{l}\text { Concentric } \\
\text { rings }\end{array}$ & $\begin{array}{c}\text { Colony } \\
\text { morphology }\end{array}$ & $\begin{array}{c}\text { Pigmentation } \\
\text { on lower side } \\
\text { of the plate }\end{array}$ & $\begin{array}{c}\text { Sporulatio } \\
\text { n initiate } \\
\text { After (hrs) }\end{array}$ \\
\hline 1. & PT-1 & $\begin{array}{l}\text { Light to } \\
\text { dark } \\
\text { green }\end{array}$ & Present & $\begin{array}{l}\text { Rough, spongy and } \\
\text { raised }\end{array}$ & $\begin{array}{l}\text { Whitish } \\
\text { creamy }\end{array}$ & $48-72$ \\
\hline 2. & PT-2 & $\begin{array}{l}\text { Light } \\
\text { green }\end{array}$ & Present & $\begin{array}{l}\text { Rough, spongy and } \\
\text { raised }\end{array}$ & $\begin{array}{l}\text { Yellowish } \\
\text { green }\end{array}$ & $48-72$ \\
\hline 3. & PT-3 & $\begin{array}{l}\text { Light to } \\
\text { dark } \\
\text { green }\end{array}$ & Absent & $\begin{array}{c}\text { Smooth, flat and } \\
\text { dense sporulation at } \\
\text { border }\end{array}$ & Pinkish & $48-72$ \\
\hline 4. & PT-4 & $\begin{array}{l}\text { Light to } \\
\text { dark } \\
\text { green }\end{array}$ & Present & $\begin{array}{l}\text { Rough, spongy and } \\
\text { raised }\end{array}$ & $\begin{array}{l}\text { Yellowish } \\
\text { green }\end{array}$ & 48 \\
\hline 5. & PT-5 & $\begin{array}{l}\text { Dark } \\
\text { green }\end{array}$ & Absent & Spongy and fluffy & Yellowish & 48 \\
\hline 6. & PT-6 & $\begin{array}{l}\text { Whitish } \\
\text { to light } \\
\text { green }\end{array}$ & Present & $\begin{array}{l}\text { Rough, spongy and } \\
\text { raised }\end{array}$ & $\begin{array}{l}\text { Whitish } \\
\text { creamy }\end{array}$ & $48-72$ \\
\hline 7. & PT-7 & $\begin{array}{l}\text { Light to } \\
\text { dark } \\
\text { green }\end{array}$ & Present & $\begin{array}{l}\text { Rough, spongy and } \\
\text { raised }\end{array}$ & $\begin{array}{l}\text { Yellowish } \\
\text { green }\end{array}$ & 48 \\
\hline 8. & PT-8 & $\begin{array}{l}\text { Dark } \\
\text { green }\end{array}$ & Present & $\begin{array}{l}\text { Rough, spongy and } \\
\text { raised }\end{array}$ & Yellowish & 48 \\
\hline 9. & PT-9 & $\begin{array}{l}\text { Light to } \\
\text { dark } \\
\text { green }\end{array}$ & Present & $\begin{array}{l}\text { Rough, spongy and } \\
\text { raised }\end{array}$ & $\begin{array}{l}\text { Whitish } \\
\text { creamy }\end{array}$ & 48 \\
\hline 10. & PT-10 & $\begin{array}{l}\text { Dark } \\
\text { green }\end{array}$ & Present & $\begin{array}{l}\text { Rough, spongy and } \\
\text { raised }\end{array}$ & $\begin{array}{l}\text { Whitish } \\
\text { creamy }\end{array}$ & $48-72$ \\
\hline 11. & DDNT-1 & $\begin{array}{l}\text { Light to } \\
\text { dark } \\
\text { green }\end{array}$ & Present & $\begin{array}{l}\text { Rough, spongy and } \\
\text { raised }\end{array}$ & $\begin{array}{l}\text { Yellowish } \\
\text { green }\end{array}$ & 72 \\
\hline 12. & DDNT-2 & $\begin{array}{l}\text { Light to } \\
\text { dark } \\
\text { green }\end{array}$ & Present & $\begin{array}{l}\text { Rough, spongy and } \\
\text { raised }\end{array}$ & $\begin{array}{l}\text { Whitish } \\
\text { creamy }\end{array}$ & $48-72$ \\
\hline 13. & DDNT-3 & $\begin{array}{l}\text { Dark } \\
\text { green }\end{array}$ & Present & $\begin{array}{l}\text { Rough, spongy and } \\
\text { raised }\end{array}$ & $\begin{array}{l}\text { Yellowish } \\
\text { green }\end{array}$ & $48-72$ \\
\hline 14. & DDNT-4 & $\begin{array}{l}\text { Whitish } \\
\text { to light } \\
\text { green }\end{array}$ & Absent & Smooth and flat & Light brown & 48 \\
\hline 15. & DDNT-5 & $\begin{array}{l}\text { Light } \\
\text { green }\end{array}$ & Absent & Smooth and flat & Yellowish & 48 \\
\hline
\end{tabular}


Table.3 Morphological characteristics of Trichoderma isolates

\begin{tabular}{|c|c|c|c|c|c|c|}
\hline S.No & $\begin{array}{l}\text { Trichoderma } \\
\text { isolates }\end{array}$ & $\begin{array}{c}\text { Phialide } \\
\text { dispositio } \\
\text { n }\end{array}$ & Phialide shape & $\begin{array}{l}\text { Conidia } \\
\text { shape }\end{array}$ & $\begin{array}{l}\text { Conidia } \\
\text { colour }\end{array}$ & Chlamydospores \\
\hline 1. & PT-1 & $2-4$ & Lageniform & $\begin{array}{l}\text { Globose to } \\
\text { subglobose }\end{array}$ & Green & Terminal \\
\hline 2. & PT-2 & $2-4$ & Ampulliform & $\begin{array}{l}\text { Globose to } \\
\text { subglobose }\end{array}$ & Green & $\begin{array}{l}\text { Terminal and } \\
\text { intercalary }\end{array}$ \\
\hline 3. & PT-3 & $2-3$ & Lageniform & Globose & Green & $\begin{array}{l}\text { Terminal and } \\
\text { intercalary }\end{array}$ \\
\hline 4. & PT-4 & $2-4$ & Ampulliform & $\begin{array}{l}\text { Globose to } \\
\text { subglobose }\end{array}$ & Green & Terminal \\
\hline 5. & PT-5 & $2-3$ & Ampulliform & $\begin{array}{l}\text { Globose to } \\
\text { subglobose }\end{array}$ & Green & $\begin{array}{l}\text { No chlamydospore } \\
\text { formation }\end{array}$ \\
\hline 6. & PT-6 & $2-4$ & Lageniform & $\begin{array}{l}\text { Globose to } \\
\text { sublglobose }\end{array}$ & Green & $\begin{array}{l}\text { Terminal and } \\
\text { intercalary }\end{array}$ \\
\hline 7. & PT-7 & $2-3$ & Ampulliform & $\begin{array}{l}\text { Globose to } \\
\text { subglobose }\end{array}$ & Green & Intercalary \\
\hline 8. & PT-8 & $2-3$ & Lageniform & $\begin{array}{l}\text { Globose to } \\
\text { subglobose }\end{array}$ & Green & $\begin{array}{l}\text { Terminal and } \\
\text { intercalary }\end{array}$ \\
\hline 9. & PT-9 & $2-3$ & Lageniform & Globose & Green & Intercalary \\
\hline 10. & PT-10 & $2-3$ & Ampulliform & $\begin{array}{l}\text { Globose to } \\
\text { subglobose }\end{array}$ & Green & Intercalary \\
\hline 11. & DDNT-1 & $2-4$ & Ampulliform & $\begin{array}{l}\text { Globose to } \\
\text { subglobose }\end{array}$ & Green & $\begin{array}{l}\text { Terminal and } \\
\text { intercalary }\end{array}$ \\
\hline 12. & DDNT-2 & $2-3$ & Lageniform & $\begin{array}{l}\text { Globose to } \\
\text { ellipsoidal }\end{array}$ & Green & Intercalary \\
\hline 13. & DDNT-3 & $2-3$ & Lageniform & $\begin{array}{l}\text { Globose to } \\
\text { subglobose }\end{array}$ & Green & $\begin{array}{c}\text { Terminal and } \\
\text { intercalary }\end{array}$ \\
\hline 14. & DDNT-4 & $2-3$ & Ampulliform & $\begin{array}{l}\text { Globose to } \\
\text { subglobose }\end{array}$ & Green & Terminal \\
\hline 15. & DDNT-5 & $2-3$ & Ampulliform & $\begin{array}{l}\text { Globose to } \\
\text { subglobose }\end{array}$ & Green & $\begin{array}{c}\text { Terminal and } \\
\text { intercalary }\end{array}$ \\
\hline
\end{tabular}

Table.4 Grouping of Trichoderma isolates based on the morphological characters

\begin{tabular}{|c|c|c|c|}
\hline S.No. & Group & Isolates & Characteristics features \\
\hline $\mathbf{1 .}$ & Group I & $\begin{array}{c}\text { PT-2, PT-4, PT-5, PT-7, PT-10, } \\
\text { DDNT-1, DDNT-4 and DDNT-5 }\end{array}$ & $\begin{array}{c}\text { Phialides: Ampulliform } \\
\text { Conidia: Globose to subglobose }\end{array}$ \\
\hline $\mathbf{2 .}$ & Group II & PT-3 and PT-9 & $\begin{array}{c}\text { Phialides: Lageniform } \\
\text { Conidia: Globose }\end{array}$ \\
\hline $\mathbf{3 .}$ & Group III & PT-1, PT-6, PT-8 and DDNT-3 & $\begin{array}{c}\text { Phialides: Lageniform } \\
\text { Conidia: Globose to subglobose }\end{array}$ \\
\hline $\mathbf{4 .}$ & Group IV & DDNT-2 & $\begin{array}{c}\text { Phialides: Lageniform } \\
\text { Conidia: Globose to ellipsoidal }\end{array}$ \\
\hline
\end{tabular}



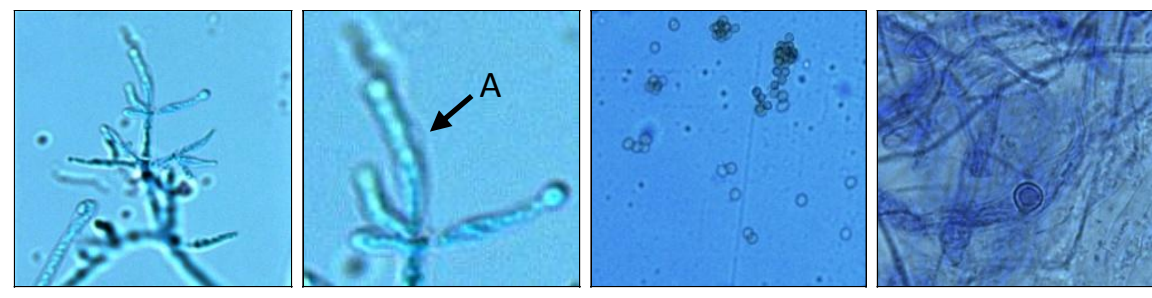

PT-1
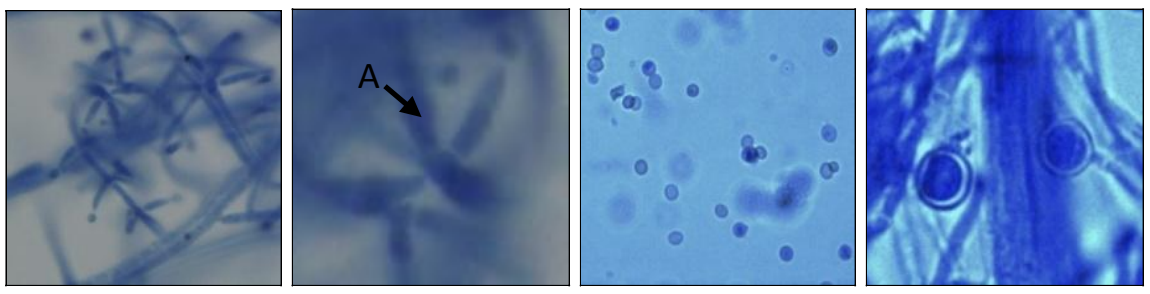

PT-10
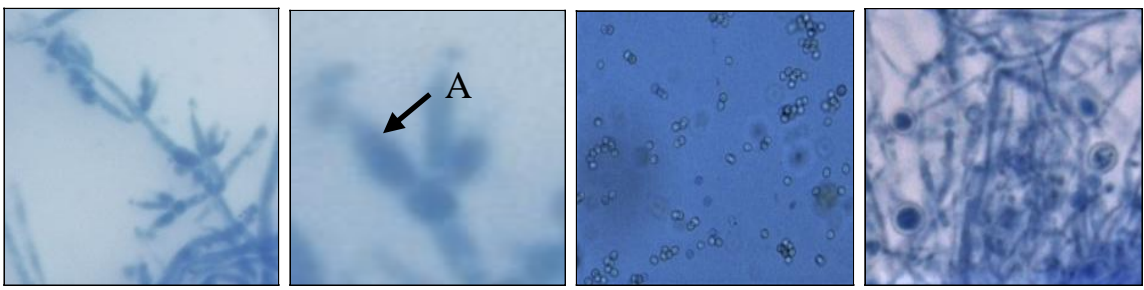

DDNT-1
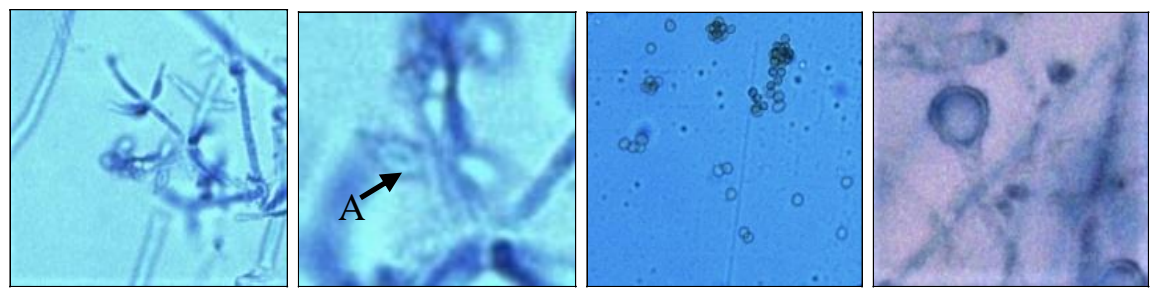

\section{DDNT-4}

Fig.1 Conidiophores Phialides Conidia Chlamydospores
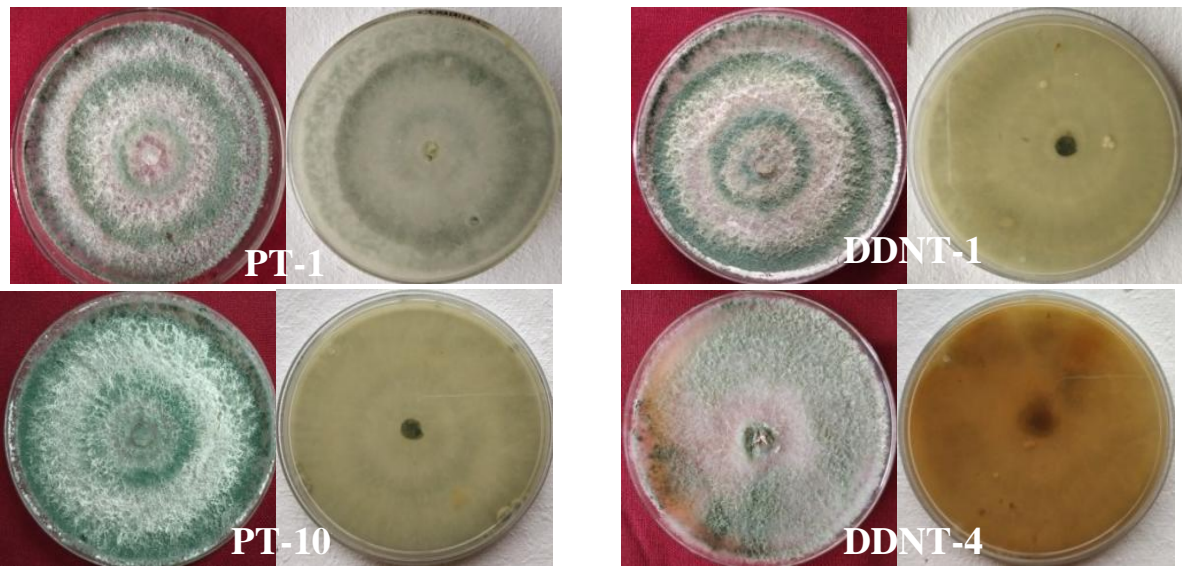

Plate.1 Cultural characteristics of Trichoderma isolates 
Trichoderma was divided into nine species aggregate which was based on morphological characteristics (Rifai and Webster, 1996) and morphological characterization was done based on key provided by Bissett (1991 a and b) which included characters like colony colour, colony morphology and spore pattern. Similarly, Kiffer and Morelet (2000) grouped Trichoderma isolates on colony colour, pigmentation, conidiophores and phialide characters.

The morphological characteristics like branching pattern of conidiophores, shape and size of phialides, conidia and formation of chlamydospores are frequently observed for identification of Trichoderma (Gams and Bissett 2002; Samuels et al., 2002). Isolates of Trichoderma were identified up to species level based on morphological characteristics such as size and shape of conidiophores, conidia and phialides (Srivastava et al., 2014).

\section{References}

Bissett, J. 1991a. A revision of the genus Trichoderma. II. Infrageneric classification, Canadian Journal of Botany, 69: 23572372.

Bissett, J. 1991b. A revision of the genus Trichoderma. III. Sect. Pachybasium, Canadian Journal of Botany, 69: 23732417.

Elad, Y., Chet, L. and Henis, Y. 1981. A selective medium for improving quantitative isolation of Trichoderma spp. from soil. Phytoparasitica, 9(1): 59-67.

Erayya. 2014. Designing a triple combination of copper, Trichoderma and chitosan and its evaluation against late blight caused by Phytophthora infestans (Mont.) de Bary. Thesis, Ph.D. G.B. Pant University of Agriculture and Technology, Pantnagar. pp. 65-90.

Gams, W. and Bissett, J. 2002. Morphology and identification of Trichoderma. In: Kubicek,
C.P. and Harman, G.E. eds. Trichoderma and Gliocladium: Basic biology, taxonomy and genetics. Taylor and Francis, London. pp. 3-31.

Kiffer, E. and Morelet, E. 2000. The Deuteromycetes mitosporic fungi classification and generic keys. Science publications, USA. $300 \mathrm{pp}$.

Krassilnikov, N. A. 1950. Actinomycetes antagonists and antibiotic substances (in Russian). Academy of Sciences, U.S.S.R., Mascow, Leningrad. pp. 65-66.

Mukherjee, P.K. 1991. Biological control of chickpea wilt complex. Thesis, Ph.D G.B. Pant University of Agriculture and Technology, Pantnagar. 188p.

Rifai, M.A. and Webster, J. 1996. Culture studies on Hypocrea and Trichoderma II. $H$. aureoviridis and $H$. rufa, $F$. sterilis, $F$. nov. Transactions of the British Mycological Society, 49(2): 289-296.

Samuels, G.J., Dodd, S.L., Gams, W., Castlebury, L.A. and Petrini, O. 2002. Trichoderma species associated with the green mold epidemic of commercially grown Agaricus bisporus. Mycologia, 94: 146-170.

Samuels, G.J., Dodd, S.L., Gams, W., Castlebury, L.A. and Petrini, O. 2002. Trichoderma species associated with the green mold epidemic of commercially grown Agaricus bisporus. Mycologia, 94: 146-170.

Seaby, D.A. 1996. Differentiation of Trichoderma taxa associated with mushroom production. Plant Pathology, 45: 905-912.

Sharma, K.K. 2009. Morphological and molecular characterization of rhizospheric isolates of Trichoderma and determination of their biocontrol efficacy. Thesis, Ph.D. G.B. Pant University of Agriculture and Technology, Pantnagar. pp. 65-95.

Srivastava, M., Singh, A. and Srivastava, D.K. 2014. Morphological and molecular characterization of Trichoderma isolates: An antagonist against soil borne pathogens. International Journal of Science and Research, 3(7): 2399-2404. 


\section{How to cite this article:}

Priya Singh and Manju Sharma. 2020. Cultural and Morphological Characterization of Antagonistic Trichoderma Isolates. Int.J.Curr.Microbiol.App.Sci. 9(03): 1041-1048. doi: https://doi.org/10.20546/ijcmas.2020.903.122 